\title{
THE CORRELATION OF CT FINDINGS AND IN-HOSPITAL MORTALITY AFTER CEREBRAL INFARCTION
}

\author{
CHARLES ANDRE** RUBENS S.A. PINHEIRO**
}

\begin{abstract}
SUMMARY - Objective: To evaluate whether findings on computed tomography (CT) are useful to predict early mortality after acute cerebral infarction. Methods: An admission CT was performed in 98 patients with disease-onset within 7 days; CT findings were analyzed using a checking list; their influence on hospital mortality was studied by logistic regression analysis. Results: There were 29 hospital deaths. Uncal herniation and midline shift $>4 \mathrm{~mm}$ were strongly correlated with fatal outcome. Also associated with increased mortality: infarction of a whole hernisphere or in the distribution of internal carotid artery; massive ( $>90 \%$ expected area) infarction in the territory of the anterior or posterior cerebral arteries; massive or submassive ( $>50 \%$ expected area) middle cerebral artery infarction; large lesion volume (death in $9 / 13$ patients with lesions $>50 \mathrm{~cm}^{3}$ ); any degree of mass effect. In 68 patients with single middle cerebral artery lesions, extension of the lesion to adjacent vascular territories was also associated with a worse outcome. The number of lesions and the presence of contrast enhancement, hemorrhagic changes or cerebral atrophy did not influence outcome. Conclusions: CT findings indicating significant mass effect and large infarcts are associated with mortality after ischemic stroke. The best combination of clinical and CT variables to estimate death risk in individual patients remains to be determined.
\end{abstract}

KEYWORDS: cerebral infarction, cerebrovascular disorders, cerebral hernia, mortality, prognosis, CT scan.

\section{Correlação entre achados à TC e letalidade hospitalar após infarto cerebral}

RESUMO - Objetivo: Avaliar a importância dos achados à tomografia computadorizada (TC) na determinaçāo do risco de vida precoce após o infarto cerebral. Métodos: 98 pacientes com infarto cerebral com até 7 dias de evoluçāo foram estudados por TCà admissão; os achados à TC foram avaliados de modo padronizado; a influência destes achados sobre a letalidade hospitalar foi estudada por análise de regressão logística. Resultados: 29 pacientes faleceram durante a internação. Herniação de unco e desvio de estruturas de linha média superior a 4 $\mathrm{mm}$ associaram-se fortemente ao risco de vida elevado. Outros fatores positivamente relacionados: infarto hemisférico ou ocupando o território carotídeo (a. cerebral anterior e a. cerebral média); infarto maciço ( $>90 \%$ da área esperada) no território das artérias cerebrais anterior ou posterior; infarto maciço ou submaciço ( $>50 \%$ da área esperada) no território da artéria cerebral média; grande volume de lesão (morte em $9 / 13$ pacientes com lesão $>50 \mathrm{~cm}^{3}$ ); qualquer grau de efeito de massa. Em 68 pacientes com lesōes únicas no território da artéria cerebral média, a extensão da lesão a territórios vasculares adjacentes também associou-se a pior prognóstico. $O$ número de lesōes e a presença de captação de contraste, transformação hemorrágica ou de atrofia cerebral nāo influenciaram a evolução. Conclusōes: Os achados de importante efeito de massa e grandes lesões à TC associamse fortemente a alta letalidade hospitalar após o infarto cerebral. Deve-se agora determinar a combinação de variáveis clínicas e tomográficas que melhor prevê o risco de vida em pacientes individuais.

PALAVRAS-CHAVE: desorderns cérebro-vasculares, hérnia cerebral, infarto cerebral, mortalidade, prognóstico, tomografia computadorizada.

From the Departments of Neurology" and Radiology“", Hospital Universitário Clementino Fraga Filho. Universidade Federal do Rio de Janeiro (UFRJ). Aceite:14-março-1995. 
Computerized tomography (CT) has become a standard diagnostic tool for initial evaluation of patients with acute stroke. It is a reliable instrument to differentiate hemorrhagic and ischemic stroke. CT and/or magnetic resonance imaging criteria will certainly be established to rapidly select patients with acute cerebral infarction (CI) for more active and urgent therapy, such as intravenous thrombolysis ${ }^{22}$.

Although several CT findings correlate with increased case-fatality rates after cerebral hemorrhage, we are not aware of any systematic evaluation of the prognostic value of CT after acute CI. We studied the possible correlation between CT findings in the first week following CI and early death risk.

\section{PATIENTS AND METHODS}

We analyzed CT data prospectively collected from all adult patients $(\geq 20$ years old) admitted with a diagnosis of acute CI between Januuary 1986 and December 1987 at our institution. Only patients admitted within one week of disease onset were included. Diagnosis of the stroke syndrome was based on widely accepted clinical criteria". Patients with a clinical diagnosis of infratentorial ischemic stroke were excluded.

All paticnts had at least one admission CT performed to exclude alternative diagnoses such as intracranial hemorthage or tumor. Findings from these admission CT scans made in the first week after disease-onset are the main subject of this study. Additional CTs were made upon request from the attending physicians but are not considered here.

CT was performed in all patients using a SOMATON DR2 scanner (Siemens; image matrix: 256x256 pixels), with 4 and $8 \mathrm{~mm}$ thickness slices. All exams were jointly analyzed by the authors, using a checking list. Consensus was always reached on all aspects of this analysis

The exact site of the acute lesion(s) was determined by visual comparison with the charts from Berman and cols. ${ }^{4,513}$. Lesions were classified as situated in one of the following vascular territories: anterior cerebral artery ; middle cerebral artery; posterior cerebral artery; internal carotid artery (anterior + middle cerebral arteries); hemispheric infarction; and watershed. Diagnosis of a watershed infarction was made if more than one third of the infarction volume occupied each of two adjacent vascular territories (anterior-posterior, anteriormiddle, middle-posterior cerebral arteries). A lesion was considered to disrespect neurovascular limits if less than one third of $\mathrm{jts}$ volume was in a vascular territory adjacent to the main site of the lesion.

A semiquantitative analysis of the extension of lesions in the distribution of anterior, middle or posterior cerebral arteries was carried out: massive lesion, $>90 \%$ of the expected area; submassive lesion, $50-90 \%$ of the expected area; small lesion, $<50 \%$ of the expected area. Furthermore, in all cases with visible infarctions, a volumetric calculation of the lesion was made by one of the authors (CA). Thus, the area of hypodensity in each slice was reproduced after superposition of a millimeter chart and calculated by plannimetric methods'. The scale present in each CT slice was used to convert this image area from arbitrary units to squared centimeters $\left(\mathrm{cm}^{2}\right)$. Each calculated area was then multiplied by the slice thickness for infarction volume estimation $\left(\mathrm{cm}^{3}\right)$.

The following independent variables were analyzed - 1. Detection of one or more hypodensities. 2. Number of acute lesions. 3. Site of lesion(s). 4. Extension of lesion(s). 5. Infarction volume. 6. Contrast enhancement (in 77 patients). 7. Disrespect to neurovascular limits. 8. Hemorrhagic infarct. 9. Mass effect: any degree (including sulcal effacement); ipsilateral ventricular compression; contralateral shift of midline structures, in $\mathrm{mm}$ (greatest shift found: pineal gland and septum pellucidum analyzed in each case); medial temporal herniation; midline shift $>4 \mathrm{~mm}$ or medial temporal herniation. 10. Previous lesion(s). 11. Cerebral atrophy.

The main dependent variable studied was death during hospitalization. A secondary end point was death within 30 days of admission. Hospital death risk was also analyzed in two subgroups of patients: those with any visible acute hypodensity and those with a single acute hypodensity in the MCA territory. A logistic regression analysis was performed ${ }^{6}$. Results are expressed as a list of factors independently correlated with an increased death risk. Statistical significance was attributed to $p$ values $\leq 0.05$.

\section{RESULTS}

During the study period 109 patients were admitted to the hospital with an acute brain infarct. Of these, 98 had a cerebral (supratentorial) infarct. The main clinical features of these 98 patients 
Table 1. Clinical features.

\begin{tabular}{|c|c|c|c|}
\hline Variable & & $\%$ & $(\mathrm{~N})$ \\
\hline Age (avg) & $57 \pm 17$ years & & \\
\hline Gender & $\begin{array}{l}\text { male } \\
\text { female }\end{array}$ & $\begin{array}{l}54 \\
46\end{array}$ & $\begin{array}{l}(53) \\
(45)\end{array}$ \\
\hline $\begin{array}{l}\text { First stroke } \\
\text { Mechanism' }\end{array}$ & $\begin{array}{l}\text { I.a.thrombosis } \\
\text { embolism } \\
\text { undefined }{ }^{2} \\
\text { lacunar } \\
\text { other }\end{array}$ & $\begin{array}{c}87 \\
41 \\
4 I \\
8 \\
5 \\
5\end{array}$ & $\begin{array}{l}(85) \\
(40) \\
(40) \\
(8) \\
(5) \\
(5)\end{array}$ \\
\hline $\begin{array}{l}\text { Time from onset to } \\
\text { admission }\end{array}$ & $\begin{array}{l}0 \text { (inhospital) } \\
<24 \text { hours } \\
1-3 \text { days } \\
3-7 \text { days }\end{array}$ & $\begin{array}{l}17 \\
53 \\
13 \\
17\end{array}$ & $\begin{array}{l}(17) \\
(52) \\
(12) \\
(17)\end{array}$ \\
\hline Motor deficit & $\begin{array}{l}\text { massive }^{3} \\
\text { incomplete } \\
\text { normal strenght }\end{array}$ & $\begin{array}{c}42 \\
52 \\
6\end{array}$ & $\begin{array}{l}(42) \\
(51) \\
(5)\end{array}$ \\
\hline Level of consciousness & $\begin{array}{l}\text { normal } \\
\text { altered }{ }^{4} \\
\text { coma }\end{array}$ & $\begin{array}{c}48 \\
45 \\
7\end{array}$ & $\begin{array}{l}(47) \\
(44) \\
(7)\end{array}$ \\
\hline $\begin{array}{l}\text { Brainstem dysfunctions } \\
\text { Hospital death }\end{array}$ & & $\begin{array}{l}20 \\
30\end{array}$ & $\begin{array}{l}(20) \\
(29)\end{array}$ \\
\hline Mechanism & $\begin{array}{l}\text { neurologic insult } \\
\text { cardiovascular } \\
\text { infection }\end{array}$ & $\begin{array}{l}31 \\
38 \\
31\end{array}$ & $\begin{array}{c}(9 / 29) \\
(11 / 29) \\
(9 / 29)\end{array}$ \\
\hline
\end{tabular}

avg, average; \pm , standard deviation; I.a.thrombosis, large artery atherothrombosis. 1. Diagnostic criteria for clinical distinction between I.a.thrombosis and embolism are derived from the National Survey of Stroke (see; Walker AE, Robins M. Weinfield FD. Clinical findings. In: Weinfield FD (ed.). The National Survey of Stroke 1981, 12 (Suppl 1): 13-44). The routine use of CT at admission eliminated various degrees of uncertainty present in the original classification. 2. Cardiac source but with gradual onset ( $>6$ hours), with no angiogram. 3. At least one limb with no visible movement. 4. Confusion, delirium, hypersomnia, stupor. 5. Altered brainstem reflexes, pupillary or respiratory pattern changes.

are presented in Table 1. A detailed description of the whole series of 109 patients can be found elsewhere'.

Twenty-nine patients (29.6\%) died during hospitalization, 22 in the first 30 days. Age did not correlate with clinical outcome (mean \pm sd values in surviving patients: $56 \pm 17$ years; in deceased patients: $59 \pm 16$ years). Also, case-fatality rates did not differ in patients with embolic stroke or large artery atherothrombosis.

An acute hypodensity was seen in all but seven cases (93\%). Some degree of mass effect was evident in 54 of these 91 cases and hemorrhagic change in 22 cases. Contrast enhancement was present in 45 of 77 patients in which it was used. Visible lesions were distributed as follows: multiple lesions, 11 ( 8 with middle cerebral artery lesions); middle cerebral artery, 68; posterior cerebral artery, 4; anterior cerebral artery, 1; watershed, 3 (two additional cortical-subcortical lesions were included under "middle cerebral artery"); internal carotid artery or hemispheric, 4.

Acute CI was diagnosed in seven cases without a visible lesion. These patients exhibited a typical clinical picture in the presence of significant focal mass effect (four cases) or a normal CT (three cases).

Table 2 presents the significant correlates for hospital deaths. Visible herniation of medial portions of the temporal lobe was associated with a fatal outcome in 8 of 10 cases. The presence of 
Table 2. Significant correlations with hospital death: logistic regression analysis.

\begin{tabular}{lcc}
\hline Variable & p value & $(\mathrm{n})^{*}$ \\
\hline Uncal hermiation & 0,0004 & $(8 / 10)$ \\
$\begin{array}{l}\text { Uncal hemiation and/or midline } \\
\text { shift }>4 \mathrm{~mm}\end{array}$ & 0,0073 & $(9 / 15)$ \\
Midline shift $>4 \mathrm{~mm}$ & 0,009 & $(8 / 13)$ \\
Massive ACA, MCA, PCA lesion & 0,01 & $(15 / 32)$ \\
or ICA/hemispheric infarction & 0,011 & \\
$\begin{array}{l}\text { Increasing lesion volume } \\
\text { Hemispheric/ICA lesion }\end{array}$ & 0,017 & $(3 / 4)$ \\
Any dcgree of mass effect & 0,0186 & $(22 / 57)$ \\
Massive or submassive MCA lesion & 0,023 & $(13 / 28)$ \\
or ICA/hemispheric lesion & &
\end{tabular}

* (number of deaths/number of patients with variable).

Two variables exhibited limiar significance ( $p$ value between 0.05 and 0.1 ): ventricular copression (death in 19 of 50 cases): disrespect to neurovascular limits (death in 8 of 16 cases). There was no correlation between in-hospital mortality and the following variables: detection of one or more hypodensities; number of acute lesions; site of lesion(s); hemorrhagic change; contrast enhancement; presence of previsous lesion(s); cerebral atrophy.

MINIMUM ESTIMATED EXPECTED VALUE IS 9.97

$\begin{array}{lccc}\text { Statistic } & \text { Value } & \text { D.F. } & \text { Prob. } \\ \text { Pearson chisquare } & 0,236 & 1 & 0,6268 \\ \text { Yates corrected chisquare } & 0,056 & 1 & 0,8129\end{array}$

either uncal herniation (Fig la) or a midline shift $>4 \mathrm{~mm}$ (Fig lb) was so strongly associated with death that it tended to hide other important correlations. When these two variables were excluded from the analysis, additional correlations were found (Table 2): large infarctions in different territories, including submassive MCA lesions; large lesion volume (Fig 2); lesser degrees of mass effect.

Results are very similar when the analysis was restricted to the first 30 days after admission (data not shown), except for an additional significant association between mortality and ipsilateral ventricular compression $(\mathrm{p}=0.0042$ ). This 30 day period included all deaths directly related to neurologic insult (all but 3 in the first week).

In patients with a visible hypodensity in any territory, and specifically in 68 patients with single middle cerebral artery lesions, again the presence of various degrees of mass effect and an increasing lesion volume influenced the outcome. In these patients, however, extension of the lesion to adjacent territories was also associated with an increased case-fatality rate. Independent correlates found in patients with MCA lesions were: disrespect to neurovascular limits $(\mathrm{p}=0.0114)$; any degree of mass effect $(p=0.0195)$; ipsilateral ventricular compression $(p=0.0431)$; total lesion volume $(\mathrm{p}=0.0479)$; any degree of midline shift $(\mathrm{p}=0.0597)$.

\section{COMMENTS}

Our institution is the only large tertiary hospital in a geographical region with more than one million inhabitants. Patients with severe neurologic insults are preferentially admitted by physicians of the emergency department. This explains why this series includes a large number of patients with 


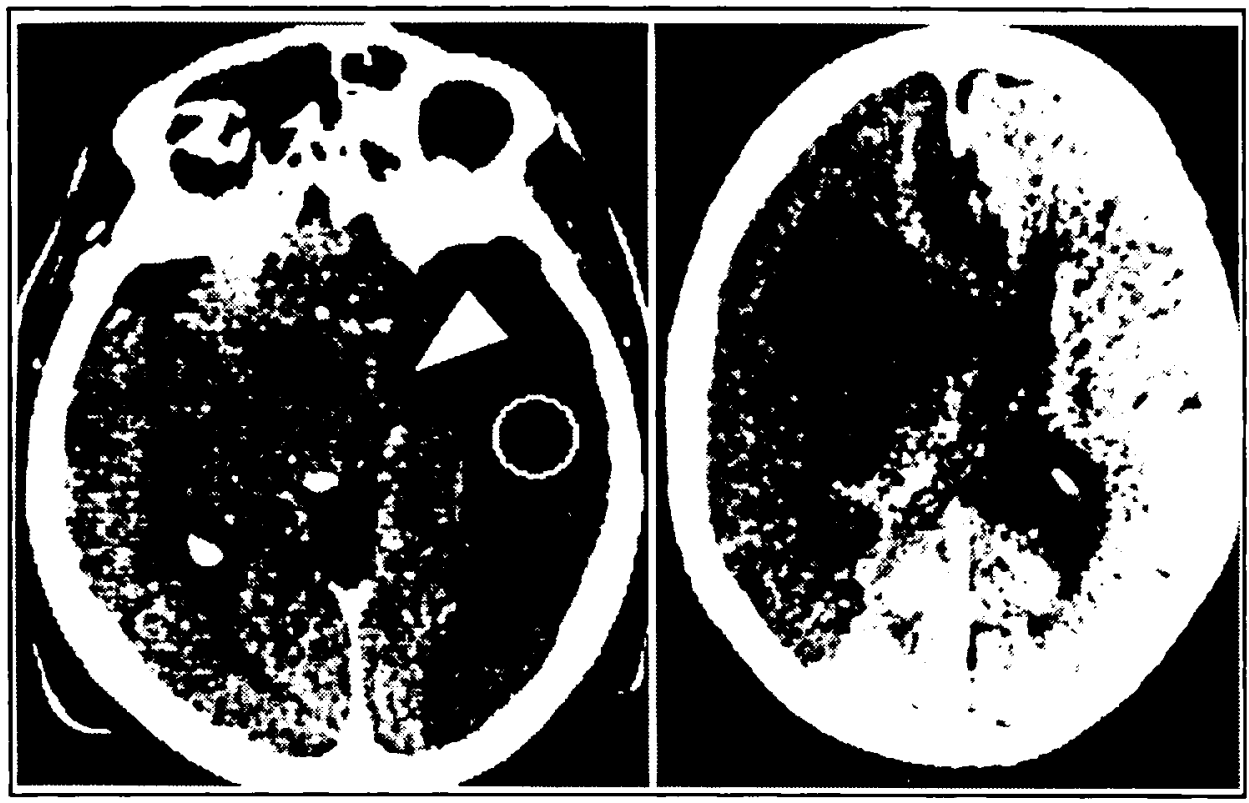

Fig 1. Main adverse CT findings. Left: herniation of portions of the left medial temporal lobe through the tentorium (arrow head) in a patient with massive middle cerebral artery infarction; the surrounded hypodense area exhibited a mean density value of $2 \mathrm{I} \mathrm{HU}$. Right: large midline shift (12 $\mathrm{mm}$ at the level of the septum pellucidum) after occlusion of the internal carotid artery; a $5 \mathrm{~cm}$ scale is shown on the right side of the figure.

massive motor deficit and early depression of consciousness, and also the high case-fatality rate detected in this study.

The main finding of this study is the demonstration of a close correlation between an increased death risk and uncal herniation and/or large midline shifts (>4 mm). This is not surprising, as these changes are consistently associated with intracranial hypertension and distortion of brainstem structures. These are the usual anatomopathologic findings in patients with an acute hemispheric mass and depressed levels of consciousness ${ }^{7,26}$.

Coma and lesser degrees of depression of consciousness are the main clinical predictors of early death after stroke ${ }^{27,20}$. Also, we ${ }^{3}$ have shown that greater accuracy in prognostic prediction of early ( 30 days) death risk following CI may be achieved if the level of consciousness two days after admission is analyzed. Obviously, patients with an initial depression of consciousness may improve if reversible factors - metabolic disturbances, reduced cardiac output - are timely recognized and treated. In some critically ill patients of this series, follow-up CT revealed an increase in hypodensity volumes during the first week after stroke. This has been recognized previously ${ }^{\star}$. Clinical worsening in these cases is probably explained by gradual development of cerebral edema and midline shift ${ }^{21.29}$. Available data thus suggest that the optimum time for accurate prognostic prediction based on CT findings is probably around 48-72 hours after disease onset.

Herniation of medial portions of the temporal lobe was associated with visible midline shifts in all but one of our cases (death in the first day following a massive hemispheric infarction). Exclusion of these two variables from multivariate analysis was necessary to find out other important prognostic correlations, especially with variables directly assessing extension of the ischemic insult. 


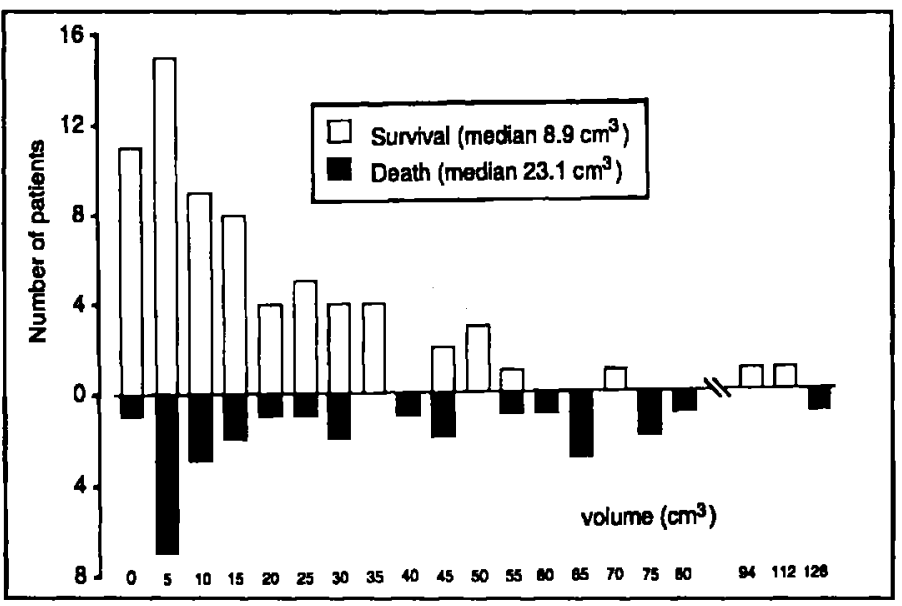

Fig 2. Lesion volume and in - hospital mortality following cerebral infarction (values for lesion volume express $5 \mathrm{~cm}^{3}$ intervals; the last three values are actual findings).

Lesion size has been used as a guide to prognosis in acute stroke since the advent of $\mathrm{CT}^{17}$. Most studies on this field have been performed in patients with hemorrhagic strokes ${ }^{10,16.27 .30,33}$. The present finding of a positive correlation in patients with $\mathrm{CI}$ is in accordance with such studies. A high death risk was detected in paticnts with a lesion volume greater than $50 \mathrm{~cm}^{3}$ : death in 9 of 13 patients (Fig 2).

Lesion size in CI patients has been correlated with stroke scale scores at admission. Saito and col. ${ }^{28}$ suggested a link between the size of hypodensity on CT and a poor outcome in patients with occlusion of the middle cerebral artery. Our results in patients with single lesions in the same territory support their findings.

Reports from two groups ${ }^{14,25}$ are in apparent disagreement with this view. Both studies, however, may have significant drawbacks. In the study from Hayman and col. ${ }^{14}$, no correlation was found between clinical outcome and the results of CT scans (size and vascular territory of the lesions). However, clinical severity of CI was subjectively assessed - probably mild in most cases - and clinical outcome measures were based on subjective comparison between the first and a very early (after 5-11 days) last examination. Rasmussen and col. ${ }^{25}$ were also unable to find a significant prognostic impact of lesion size after CI. Eleven percent of their patients, however, had intracranial hemorrhages. Also, 50 patients were excluded from study, including an unspecified number of comatose patients. These are the patients in whom survival would most likely be affected by increasing lesion volumes.

We demonstrated a prognostic correlation for disrespect of usual neurovascular limits in patients with middle cerebral artery lesions. A similar correlation was indeed suggested for the entire series $(p=0.0593)$. This finding has not been reported previously. Ischemic lesions caused by occlusion of an important artery usually does not involve its entire theoretical area of supply. The outer portions of its territory are frequently protected by collateral blood flow from adjacent vessels. On the other hand, the presence of an ischemic lesion which exceeds the usual vascular territory of a vessel is highly suggestive of an inadequate collateral flow to that region ${ }^{5}$. This insufficient collateral flow may be due to more proximal arterial obstruction or to interplaying of hemodynamic factors, eg. iatrogenic blood pressure reduction or impaired cardiac output. 
Contrast enhancement or hemorrhagic transformation were not independently associated with an increased death risk. These are important negative results from our logistic regression analysis. Conflicting reports on the prognostic influence of contrast enhancement ${ }^{24,32}$ are probably explained by lack of consideration of more important variables. Hemorrhagic transformation of $\mathrm{CI}$ has occasionally been followed by clinical deterioration ${ }^{11,15}$. This is explained by the association between hemorrhagic transformation and an embolic ethiology of $\mathrm{CI}^{12,19}$, but especially with large infarcts exhibiting significant mass effect ${ }^{15,18}$, which have been directly assessed in this study. Additional prognostic information could possibly be obtained by stratifying patients for severity of hemorrhage ${ }^{23}$. This should be further explored.

In summary, uncal herniation, midline shifts $>4 \mathrm{~mm}$ and a large infarct volume $\left(>50 \mathrm{~cm}^{3}\right)$ are all independently associated with an increased death risk after CI. Prospective studies should now establish the best combination of clinical and CT variables which must be analyzed to objectively predict clinical outcome in individual patients.

Acknowledgments - We are indebted to Dr. Maurice B. Vincent and Dr. Romeu C. Domingues for critical review of the text, and to Mrs. Rosângela A. P. Noé for statistical analysis.

\section{REFERENCES}

1. André C. A morte na fase aguda do infarto cerebral. Cronologia e causas de óbito e determinação dos fatores prognósticos adversos. Tese. Universidade Federal do Rio de Janeiro: Instituto de Neurologia Deolindo Couto. Rio de Janeiro 1991.

2. André C, Novis SAP. Determinantes prognósticos do risco de vida na fase aguda do infarto cerebral: análise de regressão múltipla em 109 casos (abstr). Arq Neuropsiquiatr 1990, 48(Supl): 25.

3. André C, Novis SAP. Distúrbios da consciência e mortalidade na fase aguda do infarto cerebral-importância central do exame neurológico sequencial (abstr). Arq Neuropsiquiatr 1990, 48(Supl): 104.

4. Berman SA, Hayman LA, Hinck VC. Correlation of CT cerebral vascular territories with function: 1. Anterior cerebral artery. Am J Roentgenol 1980, 135: 253-257.

5. Berman SA, Hayman LA, Hinck VC. Correlation of CT cerebral vascular territories with function: 3. Middle cerebral artery. Am J Roentgenol 1984, 142: 1035-1040.

6. BMDP Statistical Software Inc. BMDPLR-Stepwise logistic regression. Los Angeles: Regents of University of California, 1983.

7. Bonita R, Ford MA, Stewart AW. Predicting survival after stroke: a three-year follow-up. Stroke 1988, 19 : 669-673.

8. Brott T, Marler JR, Olinger CP et al. Measurements of acute cerebral infaretion: lesion size by computed tomography. Stroke 1989, 20: 871-875.

9. Cluzel R, Roberts JP. La géometrie et ses aplications. Paris: Delagrave,1952, p 219-221.

10. De Weerd AW. The prognosis of intraventricular hemorrhage. J Neurol 1979, 222: 45-51.

11. Drake ME, Cheolsu $S$. Conversion of ischemic to hemorrhagic infarction by anticongulant administration. Arch Neurol 1983, 40: 44-46.

12. Hakim AM, Hyder-Cooke A, Melanson D. Sequential computerized tomographic appearance of strokes. Stroke 1983, 14: 893-897.

13. Hayman LA, Berman SA, Hinck VC. Correlation of CT cerebral vascular territories with function: 2. Posterior cerebral artery. Am J Roentgenol 1981; 137: 13-19.

14. Hayman LA, Taber KH, Jhingran SG, Killian JM, Carroll RG. Cerebral infarction: diagnosis and assessment of prognosis by using ${ }^{123}$ IMP-SPECT and CT. Am J Neuroradiol 1989, 10: 557-562.

15. Hornig CR, Domdorf W, Agnoli AL. Hemorrhagic cerebral infarction: a prospective study. Stroke 1986, 17: $179-185$.

16. Jayakumar PN, Taly AB, Bhavani UR, Arya BYT, Nagaraja D. Prognosis in solitary intraventricular haemorrhage: clinical and computed tomographic observations. Acta Neurol Scand 1989, 80: 1-5.

17. Kinkel WR, Jacobs L. Computerized axial transverse tomography in cerebrovascular disease. Neurology 1976, 26: 924-930.

18. Lodder J. CT-detected hemorrhagic infarction: relation with the size of infarct, and the presence of midline shift. Acta Neurol Scand. 1984, 70: 329-335.

19. Lodder J, Krijne-Kubat B, Broekman J. Cerebral hemorrhagic infarction at autopsy: cardiac embolic cause and the relationship to the cause of death. Stroke 1986, 17: 626-629. 
20. Marquadsen J. The natural history of acute cerebrovascular disease: a prospective study of 769 patients. Acta Neurol Scand 1969, 45(Suppl.38): 1-192.

21. Ng LK, Nimmannitya J. Massive cerebral infarction with severe brain swelling: a clinicopathological study. Stroke 1970, 1: 158-163.

22. Okada Y, Sadoshima S, Nakane H, Utsunomiya H, Fujishima M. Early computed tomographic findings for thrombolytic therapy in patients with acute brain embolism. Stroke 1992, 23: 20-23.

23. Ott BR, Zamani A, Kleefield J, Funkenstein HH. The clinical spectrum of hemorrhagic infarction. Stroke 1986, 17: 630-637.

24. Pullicino P, Kendall BE. Contrast enhancement in ischaemic lesions: I. Relationship to prognosis. Neuroradiology 1980, 19: 235-239.

25. Rasmussen D, Kohler O, Worm-Petersen $\mathrm{S}$ et al. Computed tomography in prognostic stroke evaluation. Stroke 1992, 23: 506-510.

26. Ropper AH. Lateral displacement of the brain and the level of consciousness in patients with an acute hemispheral mass. N Engl J Med 1986, 314: 953-958.

27. Ruscadella J, Piero A. Prognostic factors in intraparenchymatous hematoma with ventricular hemorrhage. Neuroradiology 1986, 28: 34-37.

28. Saito I, Segawa H, Shiokawa Y, Taniguchi M, Tsutsumi K. Middle cerebral artery occlusion: correlation of computed tomography and angiography with clinical outcome. Stroke 1987, 18: 863-868.

29. Shaw C-M, Alvord EC Jr, Berry RG. Swelling of the brain following ischemic infarction with arterial occlusion. Arch Neurol 1959, 1: 161-177.

30. Steiner I, Gomor JM, Melamed E. The prognostic value of the CT scan in conservatively treated patients with intracerebral hematoma. Stroke 1984, 15: 279-282.

31. Von Arbin M, Britton M, de Faire $U$ et al. Validation of admission criteria to a stroke unit. J Chron Dis 1980, 33: 215-220.

32. Weisberg LA. Computerized tomographic enhancement patterns in cerebral infarction. Arch Neurol 1980. 37: 21-24.

33. Young WB, Lee KP, Pessin MS et al. Prognostic significance of ventricular blood in supratentorial hemomhage: a volumetric study. Neurology 1990, 40: 616-619. 